\title{
Identifikasi Aktinomiset Selulolitik dan Xilanolitik Indigenous
}

\author{
(Identification of Cellulolytic and Xylanolytic Indigenous Actinomycetes) \\ Esti Utarti ${ }^{1,2}$, Antonius Suwanto ${ }^{3}$, Maggy T. Suhartono ${ }^{4}$ dan Anja Meryandini ${ }^{3}$ \\ ${ }^{1}$ Program Studi Mikrobiologi, Departemen Biologi FMIPA IPB \\ ${ }^{2}$ Jurusan Biologi FMIPA Universitas Jember \\ ${ }^{3}$ Departemen Biologi FMIPA IPB \\ ${ }^{4}$ Departemen Teknologi Pangan Fateta IPB \\ E-mail: ameryandini@apps.ipb.ac.id
}

\begin{abstract}
Abstrak
Lignoselulosa merupakan penyusun utama dinding sel tumbuhan, sehingga keberadaannya berlimpah di alam. Aktinomiset indigenous yang memiliki aktivitas selulolitik dan xilanolitik ekstraseluler berpeluang sebagai agens biokonversi limbah berlignoselulosa menjadi produk bermanfaat. Penelitian ini bertujuan untuk mendapatkan aktinomiset potensial yang memiliki aktivitas selulolitik dan xilanolitik. Penelitian ini diawali dari isolasi dan pemurnian aktinomiset indigenous asal lahan perkebunan kelapa sawit dan Taman Nasional Bukit Duabelas Jambi. Tahapan selanjutnya adalah penapisan aktivitas selulolitik dan xilanolitik dari aktinomiset, uji pertumbuhan aktinomiset pada mikrokristalin selulosa, dan identifikasi aktinomiset potensial berdasarkan karakter morfologi, fisiologi dan biokimia. Hasil penelitian menunjukkan bahwa aktinomiset isolat S2 yang diisolasi dari lahan perkebunan kelapa sawit mempunyai aktivitas selulolitik dan xilanolitik lebih baik dari keempat isolat lain. Aktinomiset isolat S2 juga mampu tumbuh secara lebih baik pada mikrokristalin selulosa. Aktivitas selulolitik, xilanolitik dan kemampuan tumbuh pada mikrokristalin selulosa dari aktinomiset isolat S2 menunjukkan potensinya sebagai agens pendegradasi material belignoselulosa. Berdasarkan identifikasi morfologi, fisiologi dan biokimia, aktinomiset isolat S2 tergolong dalam genus Streptomyces.
\end{abstract}

Kata Kunci: Aktinomiset Indigenous, Selulolitik, Xilanolitik, Streptomyces.

\section{Abstract}

Lignocellulose is the major component of plant cell walls therefore its existence is abundant in nature. The indigenous actinomycetes that has cellulolytic and xylanolytic activities has a great possibility as the agent in bioconversion of lignocellulosic waste into the useful products. The aim of the study was to obtain the actinomycetes with the cellulolytic and xylanolytic activities. This research began with the isolation and purification of the indigenous actinomycetes from oil palm plantations and Bukit Duabelas National Park Jambi. Furthermore, screening for cellulolytic and xylanolytic from actinomycetes was conducted followed by the growth capability test of actinomycetes on microcrystalline cellulose, and the identification of potential actinomycetes with morphological, physiological and biochemical characters. The results showed that based on enzyme activity index, actinomycetes isolate $S 2$ that was isolated from oil palm plantations had cellulolytic and xylanolytic activities higher than the other four isolates. Interestingly, the actinomycetes isolate S2 is also able to grow better on microcrystalline cellulose. Along with the cellulolytic, xylanolytic activities and the growth ability on microcrystalline cellulose, the actinomycetes isolate $S 2$ shows its potential agent for degrading the lignocellulosic materials. On the basis of morphology, physiology and biochemistry characters indicated that the actinomycetes isolate S2 belongs to the genus Streptomyces.

Keywords: Indigenous Actinomycetes, Cellulolytic, Xylanolytic, Streptomyces.

\section{PENDAHULUAN}

Lignoselulosa merupakan komponen utama penyusun dinding sel tumbuhan, sehingga keberadaannya sangat berlimpah di alam. Lignoselulosa tersusun atas tiga polimer utama yakni selulosa (35-50\%), hemiselulosa (20-35\%) dan lignin (10-25\%) [1]. Selulosa sebagai komponen terbesar dari lignoselulosa, merupakan polimer yang mempunyai struktur linier homogen dari unit glukosil melalui ikatan $\beta(1 \rightarrow 4)$ yang membentuk mikrofibril berstruktur kristalin dan amorf [2]. Pada lignoselulosa, rantai linier dari ikatan $\beta-1,4$ unit glukosa saling berikatan melalui ikatan hidrogen secara intramolekuler dan intermolekuler antara gugus hidroksil dan atom oksigen yang membentuk struktur kompak yakni mikrofibril selulosa kristalin [3]. Kompleks matriks selulosa fibril tertanam dalam hemiselulosa dan lignin, sehingga mengurangi akses selulase dan hemiselulase untuk berikatan dengan substratnya sehingga mengurangi aktivitas degradasi biomassa tumbuhan [4].

Selulosa sebagai komponen utama lignoselulosa berperan sebagai bahan baku dalam industri kertas, tekstil, biofuel, makanan, obat-obatan, dan sebagai bahan dasar dan agens penstabil produk makanan. Hemiselulosa dapat dimanfaatkan dalam produksi dietary fiber, biofuel, gula rendah kalori, sebagai pelapis dan agens penstabil produk makanan, sedangkan lignin sebagai sumber fenol dan bahan baku pembuatan plastik yang dapat didegradasi. Sebagai komponen utama lignoselulosa, enzim pendegradasi selulosa dan hemiselulosa menjadi hal yang masih menarik untuk dikaji. Enzim pendegradasi lignoselulosa sangat 
berperan penting bagi industri seperti pada proses pembuatan jus buah, peningkatan daya cerna pakan ternak ruminansia, dan pemutihan kertas. Selulase dapat dimanfaatkan dalam produksi bioetanol dan biometan, industri tekstil, industri pulp dan kertas, industri pembuatan deterjen, industri makanan dan pakan ternak. Hemiselulase dapat dimanfaatkan dalam proses biobleaching, pemutihan kertas, penghilangan tinta pada limbah kertas, pencerahan jus buah dan pembuatan gula xylitol [5]. Xilanase merupakan salah satu hemiselulase yang berperan dalam proses produksi xilitol, etanol, xilooligosakarida, pada industri makanan dan pakan ternak, pengolahan pulp dan pemutihan kertas [6].

Pemanfaatan lignoselulosa melibatkan proses biokonversi yang dapat dilakukan oleh aktinomiset melalui produksi enzim lignoselulase ektraseluler. Aktinomiset merupakan salah satu mikroba penghasil selulase yang terlibat dalam degradasi utama material berlignoselulosa [7]. Aktinomiset merupakan bakteri Gram positif berfilamen. Struktur filamen aktinomiset tersebut dapat mempermudah mikrob ini dalam menembus jaringan tumbuhan sehingga meningkatkan efisiensi dalam proses degradasi biopolimer alami [8].

Rantai selulosa beragregasi membentuk mikrofibril melalui ikatan hidrogen dan interaksi van der wals. Mikrofibril ini merupakan struktur kristalin, yang menghalangi aktivitas enzim-enzim hidrolitik pendegradasi lignoselulosa untuk mencapai substratnya. Aktinomiset dengan kemampuan menghidrolisis selulosa kristalin diperlukan untuk meningkatkan efisiensi dalam biokonversi material berlignoselulosa. Oleh karena itu, penelitian ini bertujuan untuk mendapatkan dan mengidentifikasi aktinomiset yang memiliki aktivitas selulolitik dan xilanolitik.

\section{METODE PENELITIAN}

\section{Isolasi dan Pemurnian Aktinomiset}

Sampel tanah diambil dari daerah lahan perkebunan kelapa sawit dan Taman Nasional Bukit Duabelas Jambi. Aktinomiset diisolasi dengan membuat suspensi sampel tanah yang telah diberi perlakuan awal, yaitu dengan pengeringan pada suhu $60{ }^{\circ} \mathrm{C}$ selama 2 jam. Pengeringan ini bertujuan untuk mengeliminasi keberadaan cendawan dan bakteri lain terutama bakteri Gram negatif [9]. Sebanyak $1 \mathrm{~g}$ sampel tanah disuspensikan pada $10 \mathrm{~mL}$ larutan garam fisiologis $(\mathrm{NaCl} 0.85 \%)$ steril dan diinkubasi dengan inkubator bergoyang pada kecepatan $120 \mathrm{rpm}$ dalam suhu ruang selama 2 jam.

Pengenceran terhadap suspensi tanah dilakukan secara bertingkat hingga pengenceran $10^{-6}$ dalam duplikat. Sebanyak $100 \mu \mathrm{L}$ suspensi tanah dari hasil setiap pengenceran berseri diinokulasikan pada media humic acid vitamin agar (HV agar) yang mengandung humic acid (40 $\left.\mathrm{mL} \mathrm{L}^{-1}\right), \mathrm{CaCO}_{3}\left(0.02 \mathrm{~g} \mathrm{~L}^{-1}\right), \mathrm{FeSO}_{4}\left(0.01 \mathrm{~g} \mathrm{~L}^{-1}\right), \mathrm{KCl}(1.71$ $\left.\mathrm{g} \mathrm{L}^{-1}\right), \mathrm{MgSO}_{4}\left(0.05 \mathrm{~g} \mathrm{~L}^{-1}\right), \mathrm{Na}_{2} \mathrm{HPO}_{4}\left(0.5 \mathrm{~g} \mathrm{~L}^{-1}\right)$ dan bacto agar $\left(18 \mathrm{~g} \mathrm{~L}^{-1}\right)$ yang diperkaya dengan vitamin $\mathrm{B}$ kompleks $\left(5 \mathrm{ml} \mathrm{L}^{-1}\right)$ dan penambahan antibiotik nalidixic acid $(20 \mathrm{mg}$ $\left.\mathrm{L}^{-1}\right)$, dan cycloheximide $\left(0.05 \mathrm{~g} \mathrm{~L}^{-1}\right)$, dan diinkubasi dalam suhu ruang selama satu minggu. Isolat yang menunjukkan karakter morfologi koloni berbeda, dimurnikan pada media
ISP-2 (0.4 g ekstrak khamir, $1 \mathrm{~g}$ malt extract, $0.4 \mathrm{~g}$ Dglukosa dan 2 g agar dalam $100 \mathrm{~mL}$ akuades) dengan penambahan nalidixic acid dan cycloheximide.

\section{Penapisan Aktivitas Selulase (CMCase) dan Xilanase dari Isolat Aktinomiset}

Pada penapisan aktivitas CMCase dan xilanase, sebanyak 1 corckborer masing-masing isolat aktinomiset, yang telah diremajakan pada media ISP-2 selama 7 hari, diinokulasikan pada media padat CMC (carboxymethyl cellulase) dan xilan beechwood. Media padat CMC dan xilan masing-masing mengandung $0.5 \mathrm{~g} \mathrm{CMC}$ atau xilan beechwood, $0.5 \mathrm{~g}$ ekstrak khamir, $0.5 \mathrm{~g}$ bacto pepton, $0.02 \mathrm{~g}$ $\mathrm{MgSO}_{4} .7 \mathrm{H}_{2} \mathrm{O}, 0.1 \mathrm{~g} \mathrm{~K} \mathrm{~K}_{2} \mathrm{HPO}_{4} \cdot 3 \mathrm{H}_{2} \mathrm{O}$ dan $2 \mathrm{~g}$ bacto agar dalam $100 \mathrm{~mL}$ akuades. Kultur isolat aktinomiset diinkubasi pada suhu ruang selama 4 hari. Penentuan indeks aktivitas enzim dilakukan melalui uji Gram iod [10] Analisis dilakukan dengan menggenangi kultur isolat aktinomiset menggunakan larutan Gram iod selama 5 menit. Selulosa dan xilan yang telah terhidrolisis terlihat jernih pada pewarnaan Gram iod (terbentuk zona bening), sedangkan yang belum terhidrolisis berwarna biru kehitaman. Indeks aktivitas enzim (IAE) CMCase dan xilanase dihitung berdasarkan formulasi sebagai berikut:

$$
\mathrm{IAE}=\frac{(\text { diameter zona bening }- \text { diameter koloni) }}{\text { diameter koloni }}
$$

\section{Uji Kemampuan Tumbuh Aktinomiset Pada Selulosa Kristalin}

Uji kemampuan tumbuh aktinomiset pada selulosa kristalin dilakukan dengan menguji kemampuan tumbuh isolat aktinomiset pada media avicel yang masing-masing mengandung $0.5 \mathrm{~g}$ avicel, $0.5 \mathrm{~g}$ ekstrak khamir, $0.5 \mathrm{~g}$ bacto pepton, $0.02 \mathrm{~g} \mathrm{MgSO}_{4} .7 \mathrm{H}_{2} \mathrm{O}, 0.1 \mathrm{~g} \mathrm{~K}_{2} \mathrm{HPO}_{4} .3 \mathrm{H}_{2} \mathrm{O}$ dan $2 \mathrm{~g}$ bacto agar dalam $100 \mathrm{~mL}$ akuades. Masing-masing isolat aktinomiset yang telah diremajakan pada media ISP-2 selama 7 hari, diinokulasikan ke dalam media avicel dengan metode cawan gores dan diinkubasi pada suhu ruang selama 4 hari. Kemampuan tumbuh pada media avicel menunjukkan kemampuan aktinomiset mendegradasi selulosa kristalin.

\section{Identifikasi Morfologi Aktinomiset}

Identifikasi karakter morfologi aktinomiset terpilih, dengan kemampuan selulolitik dan xilanolitik terbaik, dilakukan dengan menginokulasikan isolat aktinomiset terpilih pada 4 media standar [11]. Empat media standar tersebut adalah yeast malt extract agar (ISP-2), oatmeal agar (ISP-3), inorganic salts-starch agar (ISP-4) dan glycerol-asparagine agar (ISP-5). Kultur aktinomiset terpilih diinkubasi pada suhu ruang selama 7 hari.

\section{Identifikasi Fisiologi dan Biokimia Aktinomiset}

Identifikasi karakter fisiologi dan biokimia aktinomiset yang dilakukan meliputi pengamatan pembentukan pigmen, pertumbuhan pada berbagai $\mathrm{pH}$ dan pertumbuhan pada berbagai sumber karbon. Pembentukan pigmen ditentukan dengan menginokulasikan isolat aktinomiset terpilih masing-masing pada media pepton-yeast extract agar, tyrosine agar, dan tryptone-yeast extract broth. Karakter fisiologi aktinomiset juga diamati dengan pertumbuhan 
pada media ISP-2 dalam berbagai $\mathrm{pH}$ (4-8). Pertumbuhan pada berbagai sumber karbon dilakukan dengan menginokulasikan aktinomiset pada beberapa sumber karbon (D-glukosa sebagai kontrol positif, L-arabinosa, sukrosa, D-xilosa, inositol, D-manitol, D-fruktosa, rhamnosa dan rafinosa) dalam basal mineral. Kultur diinkubasi pada suhu ruang selama 7 hari.

\section{HASIL DAN PEMBAHASAN}

\section{Aktinomiset Terpilih}

Sebanyak 5 isolat aktinomiset berhasil diisolasi dari lahan perkebunan kelapa sawit dan Taman Nasional Bukit Dua Belas, Jambi. Kelima isolat tersebut terdiri atas 2 isolat dari lahan perkebunan kelapa sawit (S2 dan S8) dan 3 isolat dari Taman Nasional Bukit Duabelas (T2, T4 dan T5). Kelima isolat tersebut memiliki karakteristik yang beragam pada beberapa karakter morfologi, diantaranya miselium substrat, miselium udara, bentuk koloni dan morfologi spora. Pada media ISP-2, kelima isolat menunjukkan konsistensi koloni yang padat, dimana koloni T2 dan T4 bersifat kering seperti bubuk. Permukaan koloni isolat S2, T2, T4 dan T5 berkerut sedangkan isolat S8 rata. Miselium substrat yang dihasilkan pada media ISP-2 oleh isolat S8 dan T2 berwarna coklat, isolat S2 dan T5 berwarna krem, sedangkan isolat T4 kuning. Empat isolat membentuk miselium udara yaitu S2 (beige), S8 (abu-abu), T2 (coklat tua) dan T5 (putih), sedangkan isolat T5 tidak membentuk miselium udara sehingga diduga merupakan kelompok rare actinomycetes.

Hasil uji aktivitas selulase pada media CMC padat menunjukkan bahwa dari 5 isolat, terdapat 4 isolat, yaitu 2 isolat dari lahan perkebunan kelapa sawit (S2 dan S8) dan 2 isolat dari Taman Nasional Bukit Duabelas (T4 dan T5), yang mempunyai aktivitas selulolitik (CMC-ase), sedangkan satu isolat (T2) tidak menunjukkan aktivitas selulolitik. Hasil uji aktivitas xilanase terhadap isolat aktinomiset yang diinokulasikan pada media beechwood xylan padat, diketahui bahwa dari kelima isolat aktinomiset mempunyai aktivitas xilanolitik (Tabel 1).

Tabel 1. Indeks aktivitas CMCase dan Xilanase

\begin{tabular}{ccc}
\hline Kode isolate & $\begin{array}{c}\text { Indeks aktivitas } \\
\text { CMCase }\end{array}$ & $\begin{array}{c}\text { Indeks aktivitas } \\
\text { xylanase }\end{array}$ \\
\hline S2 & 2.6 & 3.87 \\
S8 & 1.7 & 1.67 \\
T2 & - & 0.70 \\
T4 & 1.0 & 1.89 \\
T5 & 2.5 & 3.57 \\
\hline
\end{tabular}

Keterangan: (-) tidak memiliki aktivitas CMCase

Hasil uji aktivitas selulolitik (CMCase) dan xilanolitik menunjukkan bahwa aktinomiset isolat S2 mempunyai aktivitas selulolitik (indeks aktivitas enzim 2.6) dan aktivitas xilanolitik (indeks aktivitas enzim 3.87) lebih baik daripada keempat isolat lainnya. Indeks aktivitas selulolitik dan xilanolitik aktinomiset isolat S2 ditunjukkan pada Gambar 1

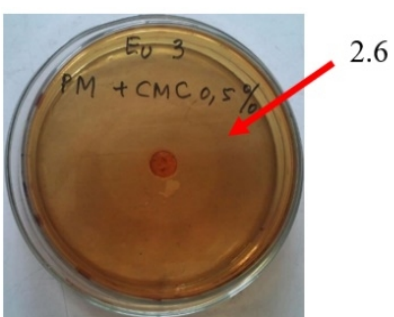

(a)

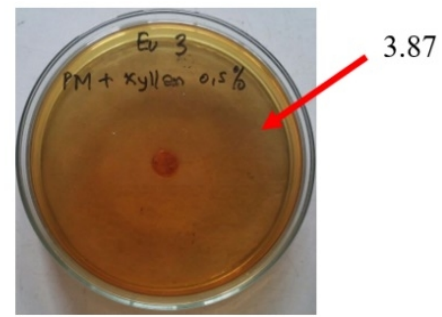

(b)
Gambar 1. Indeks aktivitas selulolitik (a) dan xilanolitik (b) aktinomiset isolat S2 masing-masing pada media CMC dan xilan beechwood agar.

Hasil penapisan terhadap aktivitas avicelase berdasarkan kemampuan pertumbuhan menunjukkan bahwa 5 isolat aktinomiset mampu tumbuh pada media pertumbuhan yang mengandung avicel sebagai satu-satunya sumber karbon (Tabel 2). Avicel merupakan selulosa mikrokristalin, sehingga kemampuan pertumbuhan isolat pada avicel menunjukkan kemampuan isolat tersebut mendegradasi selulosa kristalin. Terbukanya struktur kristalin akan mempermudah selulase dan hemiselulase dalam proses biodegradasi lignoselulosa.

Tabel 2. Pertumbuhan lima isolat aktinomiset pada media avicel

\begin{tabular}{cc}
\hline Kode isolat & Pertumbuhan pada media avicel \\
\hline S2 & +++ \\
S8 & + \\
T2 & + \\
T4 & ++ \\
T5 & ++ \\
\hline
\end{tabular}

Keterangan: $+=$ tumbuh jarang, $++=$ tumbuh sedang, +++ $=$ tumbuh baik

\section{Karakter Morfologi, Fisiologi dan Biokimia Aktinomiset Isolat S2}

Aktinomiset isolat S2 selanjutnya diidentifikasi karakter morfologi, fisiologi dan biokimia. Identifikasi karakter morfologi, fisiologi dan biokimia diperlukan karena sulit untuk menentukan karakter fenotip meskipun dilakukan analisis total genom [12]. Hasil yang diperoleh menunjukkan bahwa koloni aktinomiset isolat S2 tumbuh dengan baik pada media ISP-2, ISP-4 dan ISP-3 (Gambar 2), namun tidak tumbuh pada media ISP-5. Bentuk permukaan aktinomiset isolat S2 bulat dengan elevasi berbukit, hifa vegetatif bercabang, miselium udara berwarna beige dan bentuk spora closed spiral. Miselium substrat berwarna krem jika diinokulasikan pada media ISP-2, namun berwarna beige jika diinokulasikan pada media ISP-4 dan ISP-3. Miselium udara berwarna beige pada media ISP-2, light beige pada media ISP-3 dan ISP-4. 


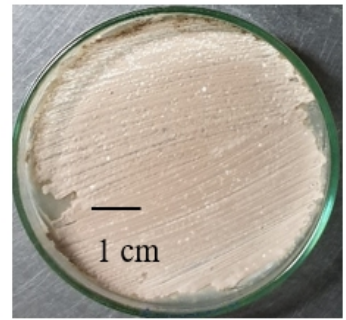

(a)

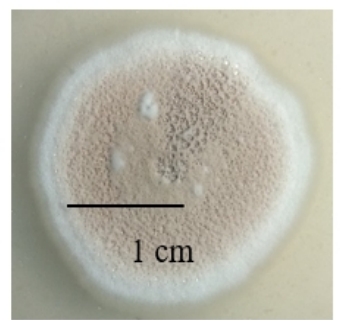

(c)

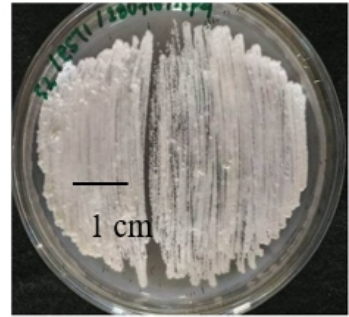

(b)

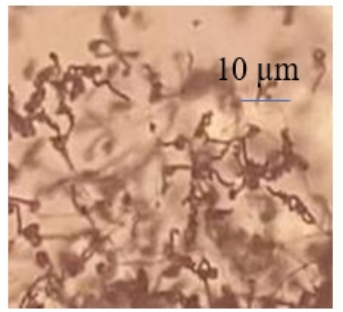

(d)
Gambar 2. Karakter morfologi koloni dari aktinomiset isolat S2 pada media ISP-2 (a), ISP-4 (b), ISP-3 (c) yang diinkubasi pada suhu ruang selama 7 hari dan morfologi spora pada perbesaran 400x.

Pada media ISP-3 dan media ISP-4, pembentukan spora oleh aktinomiset isolat S2 lebih cepat daripada media ISP-2. Media ISP-3 dan ISP-4 diketahui mengandung sumber karbon yang lebih kompleks yaitu oatmeal dan starch yang akan mempercepat pembentukan miselium udara yang selanjutnya menghasilkan spora. Berdasarkan kenampakan morfologi koloni dan bentuk rantai spora yang dimiliki, aktinomiset isolat S2 termasuk ke dalam genus Streptomyces.

Aktinomiset isolat S2 kemudian diidentifikasi lanjut berdasarkan karakter fisiologi dan biokimia. Pembentukan pigmen merupakan salah satu karakter aktinomiset yang dihasilkan baik pada media alami maupun media sintesis. Pigmen yang dihasilkan oleh aktinomiset dapat terlarut dalam medium, sehingga menyebabkan terbentuknya warna disekitar koloni, namun beberapa aktinomiset menghasilkan pigmen yang tetap berada dalam miselium. Pembentukan pigmen dipengaruhi oleh $\mathrm{pH}$ media, aerasi, suhu pertumbuhan, sumber karbon dan sumber nitrogen [13].

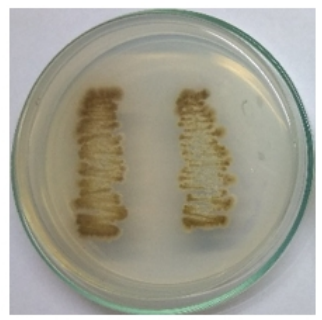

(a)

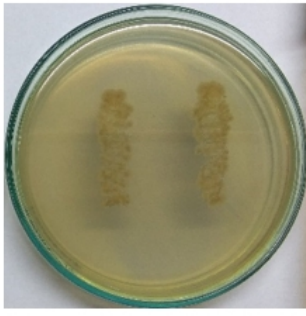

(b)

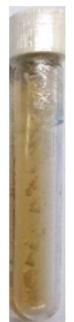

(c)
Gambar 3. Produksi pigmen aktinomiset isolat S2 pada media tirosin agar (a), peptone-yeast extract agar (b) dan tryptone-yeast extract broth (c) yang diinkubasi pada suhu ruang selama 7 hari.
Aktinomiset isolat S2 menghasilkan pigmen jika diinokulasikan pada media tyrosine agar dan tryptone-yeast extract broth setelah diinkubasi selama 7 hari pada suhu ruang (Gambar 3), namun tidak menghasilkan pigmen pada media peptone-yeast extract agar.

Pembentukan pigmen oleh aktinomiset isolat S2 pada media tyrosine agar lebih jelas daripada pada media tryptone-yeast extract broth. Tirosin merupakan asam amino utama sebagai prekusor biosintesis pigmen (melanin), sehingga kandungan tirosin pada media tyrosine agar maupun pada media tryptone-yeast extract broth mampu menstimuliasi biosintesis pigmen [14]. Tirosin merupakan sumber nitrogen utama penghasil pigmen melanin, diikuti oleh fenilalanin [15].

Aktinomiset isolat. S2 tumbuh baik dan membentuk spora pada media yang mengandung sukrosa, inositol, manitol, fruktosa, rhamnosa, rafinosa dan selulosa sebagai satu-satunya sumber karbon pada suhu ruang dengan waktu inkubasi 7 hari (Tabel 3). Pada sumber karbon glukosa, xilosa dan arabinosa, pertumbuhan aktinomiset isolat S2 ditunjukkan dengan pembentukan hifa dan miselium substrat. Pembentukan miselium udara dan spora terjadi jika aktinomiset isolat S2 diinokulasikan pada media yang mengandung sumber karbon berupa fruktosa, sukrosa, rhamnosa, rafinosa dan selulosa.

Ketika spora Streptomyces berada pada kondisi dan nutrisi yang menguntungkan, maka spora akan berkecambah dan membentuk hifa yang selanjutnya tumbuh bercabang membentuk miselium substrat atau miselium vegetatif. Namun, apabila lingkungan pertumbuhan kurang menguntungkan atau tumbuh pada nutrisi yang terbatas maka akan terjadi diferensiasi morfologi pada Streptomyces membentuk miselium udara atau miselium reproduktif yang selanjutnya akan menghasilkan spora [16]

Tabel 3. Karakter morfologi, dan fisiologi dari aktinomiset isolat $\mathrm{S} 2$

\begin{tabular}{cc}
\hline Karakteristik & \\
\hline Morfologi rantai spora & Closed spiral \\
Morfologi spora & Hairy \\
Penggunaan sumber karbon & \\
D-Glukosa & ++ \\
L-Arabinosa & + \\
D-Xilosa & + \\
D-Fruktosa & + \\
L-Rhamnosa & +++ \\
L-Rafinosa & +++ \\
D-Manitol & ++ \\
D-Inositol & ++ \\
Sukrosa & +++ \\
Selulosa & ++
\end{tabular}

Keterangan: $+=$ tumbuh jarang, $++=$ tumbuh sedang, +++ $=$ tumbuh baik

Aktinomiset isolat $\mathrm{S} 2$ mampu tumbuh pada media ISP-2 pada kisaran $\mathrm{pH}$ 5-8 selama waktu inkubasi 7 hari, namun pada $\mathrm{pH} 4$ dibutuhkan waktu lebih lama untuk tumbuh, yaitu setelah 12 hari (Gambar 4). Pada media ISP-2 pH 6 tersebut, Aktinomiset isolat S2 tumbuh lebih baik dan menunjukkan kemampuannya menghasilkan pigmen brown 
beige. Mikrob dilaporkan memiliki $\mathrm{pH}$ optimum untuk pertumbuhannya, dan pada $\mathrm{pH}$ optimum tertentu aktinomiset akan menghasilkan pigmen ektraseluler [13].

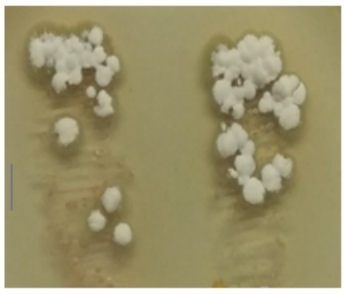

(a)

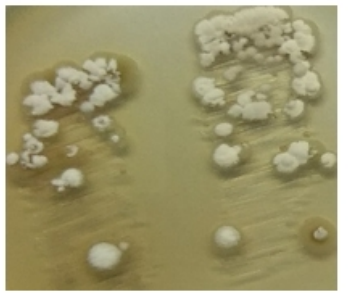

(c)

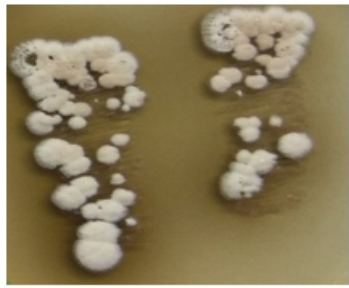

(b)

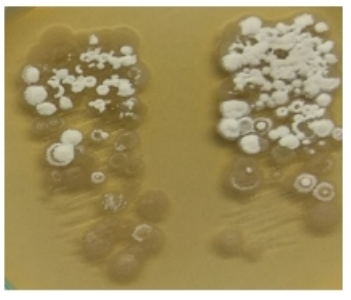

(d)
Gambar 4. Pertumbuhan isolat aktinomiset isolat S2 pada media ISP-2 pH 5 (a), 6 (b), 7 (c), dan 8 (d) yang diinkubasi pada suhu ruang selama 7 hari.

\section{KESIMPULAN}

Aktinomiset isolat S2 yang diisolasi dari lahan perkebunan kelapa sawit mempunyai aktivitas selulolitik dan xilanolitik lebih baik dari keempat isolat yang lain. Aktinomiset isolat S2 juga mempunyai kemampuan tumbuh lebih baik pada mikrokristalin selulosa. Aktivitas selulolitik, xilanolitik dan kemampuan tumbuh pada mikrokristalin selulosa dari aktinomiset isolat S2 menunjukkan potensinya sebagai agens pendegradasi material berlignoselulosa.

Berdasarkan identifikasi morfologi, fisiologi dan biokimia, aktinomiset isolat $\mathrm{S} 2$ tergolong dalam genus Streptomyces.

\section{UCAPAN TERIMA KASIH}

Ucapan terimakasih disampaikan kepada Direktorat Jenderal Penguatan Riset dan Pengembangan Kementerian Riset, Teknologi dan Pendidikan Tinggi Republik Indonesia melalui Program Penelitian Disertasi Doktor Sesuai SPK No. 1278/UN25.3.1/LT/2018 dan ABS Fund CRC 990 Research Group B02 2017 untuk Prof Dr Anja Meryandini, MS.

\section{DAFTAR PUSTAKA}

[1] Pradeep GC, Choi YH, Choi YS, Seong CN, Cho SS, Lee HJ, Yoo JC. 2013. A novel thermostable cellulase-free xilanase stable in broad range of $\mathrm{pH}$ from Streptomyces sp. CS428. Proc Biochem. 48(8): 1188-1196.

[2] Horn SJ, Vaaje-Kolstad G, Westereng B, Eijsink VGH. 2012. Novel enzymes for the degradation of cellulose. Biotechnol Biofuels. 5(1): 1-12.
[3] Ekwe E, Morgenstern I, Tsang A, Storms R, Powlowski J. 2013. Non-hydrolytic cellulose active protein: research progress and potential application in biorefineries. Ind Biotechnol. 9(3): 123-131.

[4] Dimarogona M, Topakas E, Christakopoulos P. 2013. Recalcitrant polysaccharide degradation by novel oxidative biocatalysts. Appl Microbiol Biotechnol. 97(19): 8455-8465.

[5] Saini A, Aggarwal K, Sharma A, Yadav A. 2015. Review article: Actinomycetes: a source of lignocellulolytic enzymes. Enzyme Res. 2015:1-15.

[6] Patel SJ and Savanth VD. 2015. Review on fungal xylanases and their applications. Intl. J. of $A d v$. Research. 3(3): 311-315.

[7] Prasad P, Singh T, Bedi S. 2013. Characterization of cellulytic enzyme produced by Streptomyces griseorubens (Acc No. AB184139) isolated from Indian soil. J. of King Saud Univ-Sci. 25(3): 245-250.

[8] Barka EA, Vatsa P, Sanchez L, Gaveau-Vallant N, Jacquard C, Klenk HP, Clement C, Ouhdouch Y, van Wezel GP. 2016. Taxonomy, physiology, and natural product of actinobacteria. Microbiol Mol Biol Rev. 80(1): 1-44.

[9] Jeffrey LSH. 2008. Isolation, characterization and identification of actinomycetes from agriculture soils at Semongok, Serawak. Afr J Biotechnol 7(20): 36973702.

[10] Kasana RC, Salwan R, Dhar H, Dutt S, Gulati A. 2008. A rapid and easy method for the detection of microbial cellulases on agar plates using G's iodine. Curr Microbiol. 57(5): 503-507.

[11] Shirling EB, Gottlieb D. 1966. Method for characterization of Streptomyces species. Intl J Syst Bacteriol. 16(3): 313-340.

[12] Li Q, Chen X, Jiang Y, Jiang C. 2016. Morphological Identification of Actinobacteria. In: Dhanasekaran D and Jiang Y, editor. Actinobecteria, Basics and Biotechnological Applications. Books on Demand Bharathidasan University. Tiruchirappali, India. 5986.

[13] Amal AM, Keera AA, Helmi MS, Nadia AEH, Ahmed KA, El-Hennawi HM. 2011. Selection of pigment (melanin) production in Streptomyces and their application in printing and dyeing of wool fabrics. Res J Chem Sci. 1(5): 22-28.

[14] Ando H, Kondoh H, Ichihashi M, Hearing VJ. 2007. Approaches to identify inhibitors of melanin biosynthesis via the quality control of tyrosinase. $J$ Invest Dermatol. 127(4): 751-761.

[15] Quadri SR, Agsar D. 2012. Detection of melanin producing thermo-alkaliphilic Streptomyces limestone quarries of the Deccan traps. World J Sci Technol. 2(2): 8-12.

[16] Flardh K, Buttner MJ. 2009. Streptomyces morphogenetics: dissecting differention in a filamentous bacterium. Nat Rev Micobiol. 7(1): 36-49. 